\title{
Prognostic Factors Obtained from Long-Term Follow-up of Pituitary Adenomas and Other Sellar Tumors
}

\author{
Hipofiz Adenomları ve Diğer Sellar Tümörlerin Uzun Süreli \\ Takiplerinden Elde Edilen Prognostik Faktörler
}

Halit DIRI ${ }^{1}$, Ersin OZASLAN ${ }^{2}$, Ali KURTSOY ${ }^{3}$, Bulent TUCER ${ }^{3}$, Yasin SIMSEK ${ }^{1}$, Figen OZTURK ${ }^{4}$, Ahmet Candan DURAK ${ }^{5}$, Fahri BAYRAM ${ }^{1}$

${ }^{1}$ Erciyes University, School of Medicine, Department of Endocrinology, Kayseri, Turkey

${ }^{2}$ Erciyes University, School of Medicine, Department of Medical Oncology, Kayseri, Turkey

${ }^{3}$ Erciyes University, School of Medicine, Department of Neurosurgery, Kayseri, Turkey

${ }^{4}$ Erciyes University, School of Medicine, Department of Pathology, Kayseri, Turkey

${ }^{5}$ Erciyes University, School of Medicine, Department of Radiology, Kayseri, Turkey

Corresponding Author: Halit DIRI / E-mail: halitdiri@yahoo.com

\section{ABSTRACT}

AIM: Pituitary adenomas do not have a single factor of aggressive behavior or recurrence. The objective of this study was to determine factors influencing the prognosis in pituitary adenomas.

MATERIAL and METHODS: 243 patients who were operated between January 2000 and June 2012 were included in this retrospective study. Demographic data, age at diagnosis, date of diagnosis, date of operation, type of operation, post-operative medications, pre- and postoperative hormone levels, and MRI findings were evaluated in each patient.

RESULTS: The rate of total resection of sellar tumors was less than $50 \%$ in our patient population. The prognosis was better in cases with total resection. Tumor size was a poor prognostic factor in sellar tumors. Female sex was a poor prognostic factor in acromegaly and male sex in prolactinoma. The prognosis was worse in patients with cavernous sinus invasion. In acromegaly, pre-operative level of $850 \mathrm{ng} / \mathrm{ml}$ for IGF-1 was noted as a possible prognostic cut-off value.

CONCLUSION: Long-term follow-up results of our study suggest that factors common to all sellar tumors including tumor type, tumor size, total resection, and cavernous sinus invasion and tumor type-specific factors including sex and hormone levels play important roles in the prognosis.

KEYWORDS: Pituitary adenoma, Sellar region tumor, Prognosis, Follow-up

Öz

AMAÇ: Hipofiz adenomlarının agresif davranış gösterebileceğini veya nüks edebileceğini önceden belirleyebilecek uygun bir parametre bulunmamaktadır. Çalışmanın amacı, hipofiz adenomlu hastalarda prognozu hangi faktörlerin etkilediğini belirlemektir.

YÖNTEM ve GEREÇLER: Ocak 2000 ve Haziran 2012 tarihleri arasında opere edilen 243 olgu bu retrospektif çalışmaya dahil edildi. Hastalar, demografik bilgiler, tanı yaşı, tanı tarihi, operasyon tarihi, operasyon tipi, operasyon sonrası aldıkları ilaç tedavileri, operasyon öncesi ve sonrası hipofiz hormonları ve MR bulguları açısından değerlendirildi.

BULGULAR: Olgularda sellar bölge tümörlerinin total rezeksiyon oranının \% 50'den daha az olduğu görüldü. Total rezeksiyon yapılan olguların prognozunun daha iyi olarak bulundu. Sellar tümörlerde büyüklüğün prognozu olumsuz etkilediği tespit edildi. Akromegalide kadın, prolaktinomada erkek cinsiyetin prognozu kötü idi. Kavernöz sinüs invazyonu olan hipofiz adenomu olgularında prognoz daha kötü olarak saptandı. Akromegalide preoperatif IGF-1 için $850 \mathrm{ng} / \mathrm{ml}$ değerinin prognoz açısından bir cut-off değeri olabileceği görüldü.

SONUÇ: Çalışmamızdaki uzun süreli takiplerden vardığımız sonuçlara göre tümör çeşidi, tümör büyüklüğü, total rezeksiyon ve kavernöz sinüs invazyonu gibi bütün sellar tümörlerde ortak olan faktörler ile cinsiyet ve hormon düzeyleri özellikleri gibi tümör çeşitlerine spesifik faktörler prognozda önemli rol oynamaktadır.

ANAHTAR SÖZCÜKLER: Hipofiz adenomu, Sellar bölge tümörü, Prognoz, Takip 


\section{INTRODUCTION}

Tumors within the bony complex of sella turcica are the third most common primary brain tumors after gliomas and meningiomas. Pituitary adenomas constitute $10-15 \%$ of all primary brain tumors and $85 \%$ of all sellar tumors. Pituitary adenomas are followed by craniopharyngiomas, meningiomas, Rathke cleft cysts, and other sellar region mass lesions in frequency $(18,19)$.

Although pituitary adenomas are slowly growing benign tumors, some exceed the sella and invade optic chiasm, cavernous sinus, sphenoid sinus and other neighboring regions (3). Adenomas with invasion may also infiltrate the bone and much rarely the brain. There is no single parameter to predetermine which pituitary adenoma will exhibit aggressive behavior or recurrence. However, studies have demonstrated that the prognosis might depend on patient age and sex, tumor type and size, cavernous sinus invasion and basal hormone levels in pituitary adenomas (17).

The objective of this study was to investigate demographic data, post-operative hormonal remission, recurrence, residual tissue, and re-operation rates in relation to patient age and sex, tumor type and size, optic nerve compression, cavernous sinus invasion, and hormone levels in order to determine prognostic factors in sellar tumors.

\section{MATERIALS and METHODS}

\section{Study Design}

Medical records of 243 patients who were operated by the Department of Neurosurgery and followed by the Department of Endocrinology of Erciyes University Medical School (EUMS) between January 2000 and June 2012 were investigated in this retrospective study after the local ethic committee approval. All patients were operated by the same neurosurgeon. Name, surname, age, sex, date of diagnosis, age at diagnosis, date of operation, type of operation, postoperative medications, pre- and post-operative hormone levels and magnetic resonance imaging (MRI) findings of the patients were recorded.

\section{Patients}

Study inclusion criteria were being older than 16 years, having hormone examinations before and after the operation, having MRI reports in the pre- or post-operative period, performance of immunohistochemical staining of hormone secreting or non-functioning pituitary adenomas by the Pathology department of EUMS. Exclusion criteria were being younger than 16 years, absence from post-operative follow-up visits including hormonal and radiological examination.

\section{Hormonal Assessment}

Basal levels of hormones were determined in the pre-operative and post-operative period. Additionally, various dynamic tests were performed when necessary to determine hormonal remission, recurrence or hormonal failure. Basal hormone levels including free T4 (normal: 0.88-1.72 ng/dL), thyroid stimulating hormone (TSH, normal: $0.57-5.6 \mathrm{mIU} / \mathrm{mL}$ ), adrenocorticotropic hormone (ACTH, normal: 0-46 pg/mL), cortisol (normal: $9-23 \mu \mathrm{g} / \mathrm{dL}$ ), prolactin (normal: $2-18 \mathrm{ng} / \mathrm{mL}$ ), follicle stimulating hormone (FSH), luteinizing hormone ( $\mathrm{LH})$, total testosterone (in males), estradiol (in females), and insulin-like growth factor-1 (IGF-1, reference intervals by age: 219$644 \mathrm{ng} / \mathrm{mL}$ for $18-30$ years, $140-405 \mathrm{ng} / \mathrm{mL}$ for $31-40$ years, 64-336 ng/mL for $41-50$ years, $71-284 \mathrm{ng} / \mathrm{mL}$ for $51-60$ years, 94-269 $\mathrm{ng} / \mathrm{mL}$ for $61-70$ years, $72-167 \mathrm{ng} / \mathrm{mL}$ for $71-80$ years) were measured in the laboratories of EUMS.

Methods of assays, commercial kits, and intraassay and interassay coefficients of variations were $\mathrm{GH}$ : immunoradiometric assay (IRMA), Immunotech sas-France, $1.5 \%$ and $14 \%$, IGF-1: IRMA, Immunotech sas-France, $6.3 \%$ and $6.8 \%$, and cortisol: radioimmunoassay (RIA), Immunotech s.r.o-Czech Republic, $5.8 \%$ and $9.2 \%$. Other hormone levels were measured with either one of the routinely used RIA, IRMA or chemiluminassay methods. Their commercial kits, and intra-interassay coefficients of variations were ACTH: Cisbio Bioassays-France, 6.1-5.3\%, prolactin: Siemens Advia centaur XP-USA, 2.6-4.0\%, TSH: Siemens Advia centaur XP-USA, 2.48-5.31\%, fT4: Siemens Advia centaur XP-USA, 3.33-2.50\%, FSH: Siemens Advia centaur XP-USA, 2.9-2.7\%, LH: Siemens Advia centaur XP-USA, 2.3-1.5\%, estradiol: Siemens Advia centaur XP-USA, 11.1-2.0\%, total testosterone: DIAsource immunoassays S.A.-Belgium, 4.6-6.2\%.

Post-operative hormonal remission was defined as normal IGF-1 levels by age and sex in acromegaly. Additionally, GH response to $75 \mathrm{gr}$. oral glucose testing was evaluated in patients with IGF-1 level higher than the upper limit of normal range. Post-operative hormonal remission was defined as regression of serum PRL level to normal values in prolactinoma. Similarly, the definition proposed that cortisol response to stimulation with low dose $2 \mathrm{mg}$ dexamethasone suppression test (DST) should be lower than $1.8 \mu \mathrm{g} / \mathrm{dL}$ in Cushing's disease.

Gonadotropin deficiency in pituitary failure was established by reduced basal testosterone and estradiol levels below the lower limit of normal range despite normal or decreased gonadotropin levels. TSH deficiency was diagnosed by reduced free T4 levels despite normal or decreased TSH levels. Serial cortisol measurements were performed following the intravenous administration of $1 \mu \mathrm{g}$ tetracosactrin (Synacthen, Novartis Pharma, Lion, France) in low dose ACTH stimulation testing. Adrenal failure was defined as determination of peak cortisol levels below $18 \mu \mathrm{g}$ as a result of the latter testing. $\mathrm{GH}$ deficiency was diagnosed with the insulin tolerance test (ITT). Limit value of peak GH level was determined as $<3 \mu \mathrm{g} / \mathrm{L}$ for $\mathrm{GH}$ deficiency in ITT. The diagnosis of ADH deficiency was established by evaluating serum and urine osmolalities and the response to desmopressin therapy in patients with polydipsia and polyuria.

\section{Assessment of Recurrence}

Recurrence in hormone secreting adenomas was defined as repeated increase in basal hormone levels following attain- 
ment of post-operative hormonal remission confirmed by the above mentioned testing and clinical signs. On the other hand recurrence in non-secretory tumors was defined as reemergence of the tumor in the post-operative period following total resection or increase in tumor size in tumors with residual tissue.

\section{Immunohistochemical Evaluation}

Operation materials of sellar tumors were examined by the Pathology department of EUMS. All tissues were bathed in $10 \%$ formaldehyde for 24 hours and subjected to routine tissue tracing procedures. Cross-sections of 0.4 microns were obtained following paraphine embedding. These cross-sections were stained with hematoxylin-eosin and evaluated with Olympus microscope. PRL, TSH, GH, ACTH, FSH, and LH stains were administered in each case.

\section{Radiological Evaluation}

Three-dimensional volumetric pituitary MRIs (Philips GyroscanIntera 1.5 Tesla; Best, Netherlands) were obtained in the pre-operative and post-operative follow-up of the patients at the Radiology department of EUMS. Tumor size, cavernous sinus infiltration, optic chiasm compression, and residual tissues were evaluated in pre-operative and post-operative MRI reports of the patients. Tumors $<10 \mathrm{~mm}$ were evaluated as microadenoma, tumors $\geq 10 \mathrm{~mm}$ as macroadenoma, and macroadenomas $\geq 40 \mathrm{~mm}$ as giant adenoma.

\section{Statistical Evaluation}

Descriptive statistics included mean, standard deviation, frequency and ratio. Homogeneity of the variances was tested in the variables. T-test and ANOVA (Tukey test in subgroup analyses) were used as parametric tests. Chi-square test was used in the analysis of ratios, and Fischer's Test was used when Chisquare did not comply. All statistical analyses were performed with the SPSS 15.0 software. All analyses were performed within $95 \%$ confidence interval. A p value of $<0.05$ was considered statistically significant.

\section{RESULTS}

Of the 243 patients included in the study 79 had acromegaly, 75 had nonfunctioning pituitary adenoma, 42 had prolactinoma, 7 had Cushing's disease, 2 had Thyrotropinoma (TSHoma), 15 had craniopharyngioma, 12 had meningioma, and 11 had other sellar tumors. In the latter group of other sellar tumors there were 3 Rathke cleft cysts, 3 metastases (plasmacytoma, endometrial sarcoma and lung carcinoma metastases), 2 astrocytomas, 2 chordomas, and 1 germinoma. The mean age at diagnosis was $42.5 \pm 13.4$ years in male patients and $32 \pm 15.8$ years in female patients with prolactinoma, and no significant differences were found between males and females regarding the mean age at diagnosis (Table I).

There were only 34 (14\%) microadenomas and the remaining 209 cases (86\%) were macroadenomas for a total of 243

Table I: Numbers and Mean Ages of Patients with Pituitary Adenomas and Other Sellar Tumors

\begin{tabular}{|l|c|c|c|c|c|c|} 
& Number of & Male & Female & \multicolumn{3}{|c}{ Mean Age (Years) } \\
\cline { 3 - 6 } Acromegaly & patients & & & Male & Female & Total \\
\hline Nonfunctioning pituitary adenoma & 79 & 33 & 46 & 40 & 44 & 42.3 \\
\hline Prolactinoma & 75 & 47 & 28 & 53 & 51.5 & 52 \\
\hline Cushing's disease & 42 & 20 & 22 & 42.5 & 32 & 38 \\
\hline TSHoma & 7 & 1 & 6 & 40 & 40 & 40 \\
\hline Craniopharyngioma & 2 & - & 2 & - & 44.5 & 44.5 \\
\hline Meningioma & 15 & 10 & 5 & 28 & 54 & 33 \\
\hline Other sellar tumors & 12 & 1 & 11 & 62 & 43 & 44.5 \\
\hline TOTAL & 11 & 5 & 6 & 55 & 36 & 45 \\
\hline
\end{tabular}

Table II: Classification of Pituitary Adenomas According to Tumor Sizes

\begin{tabular}{|c|c|c|c|c|}
\hline & Number of patients & Microadenoma & Macroadenoma & Giant adenoma \\
\hline Acromegaly & 79 & 20 & 59 & 5 \\
\hline Prolactinoma & 42 & 3 & 39 & 11 \\
\hline Nonfunctioning pituitary adenoma & 75 & 1 & 74 & 27 \\
\hline Cushing's disease & 7 & 7 & - & - \\
\hline TSHoma & 2 & - & 2 & - \\
\hline Craniopharyngioma & 15 & 3 & 12 & 7 \\
\hline Meningioma & 12 & - & 12 & 2 \\
\hline Other sellar tumors & 11 & - & 11 & 5 \\
\hline
\end{tabular}


cases in our study. Giant adenomas constituted 27 (36\%) of nonfunctioning pituitary adenomas, 7 (46\%) of craniopharyngiomas, and 5 (45\%) of other sellar tumors. Within the group of secretory pituitary adenomas, prolactinomas were the most common group of giant adenomas. Eleven (26\%) of the prolactinomas were giant adenomas (Table II). The rate of hormonal remission was $73.5 \%$ in microadenomas and $43.5 \%$ in macroadenomas when the relationship between sellar tumor size and prognosis was assessed $(p=0.001)$. Additionally, the rate of total resection was $85.3 \%$ in microadenomas and $27.3 \%$ in macroadenomas $(p=0.0001)$, with the re-operation rates lower in cases with microadenomas. On the other hand, post-operative residual tissue was determined in 60 (80\%) nonfunctioning pituitary adenomas, 31 (74\%) prolactinomas, and 39 (49.4\%) acromegaly cases (Table III).

Accordingly, the total resection rate was $35.6 \%$ and $36.3 \%$ in cases with pituitary adenomas and other sellar tumors, respectively. Total resection was performed in 29 out of 34 $(85.3 \%)$ cases with a tumor diameter smaller than $1 \mathrm{~cm}, 31$ out of $70(44.3 \%)$ cases with a tumor diameter of $1-2 \mathrm{~cm}$, in 19 out of $62(30.6 \%)$ cases with tumor diameter of $2-3 \mathrm{~cm}$, in 4 out of $57(7.0 \%)$ cases with tumor diameter of $3-4 \mathrm{~cm}$, and in 3 out of 20 (15\%) cases with tumor diameter greater than $4 \mathrm{~cm}$ (Figure 1). Total resection rate was $9.1 \%$ in the 77 cases with tumor diameter greater than $3 \mathrm{~cm}$ and $47.6 \%$ in the 166 cases with tumor diameter smaller than $3 \mathrm{~cm}$ when the relationship between tumor diameter and total resection rates was evaluated in the entire study population $(p=0.001)$.

Pre-operative cavernous sinus invasion was most common in cases with prolactinoma and TSHoma, and optic chiasm compression was most common in cases with nonfunctioning pituitary adenoma. The highest rates of post-operative improvement in cavernous sinus invasion and optic chiasm compression were observed in cases with acromegaly

Table III: Type of Surgery and Rates of Residues in Sellar Tumors

\begin{tabular}{|l|c|c|c|}
\hline & \multicolumn{3}{|c|}{ Type of surgery } \\
\hline & Transsphenoidal (number) & Transcranial (number) & Residual tumor (\%) \\
\hline Acromegaly & 76 & 3 & 49.4 \\
\hline Nonfunctioning pituitary adenoma & 64 & 11 & 80 \\
\hline Prolactinoma & 35 & - & 74 \\
\hline Cushing's disease & 7 & - & 14.2 \\
\hline TSHoma & 2 & 9 & 50 \\
\hline Craniopharyngioma & 6 & 12 & 54 \\
\hline Meningioma & - & & 59 \\
\hline
\end{tabular}

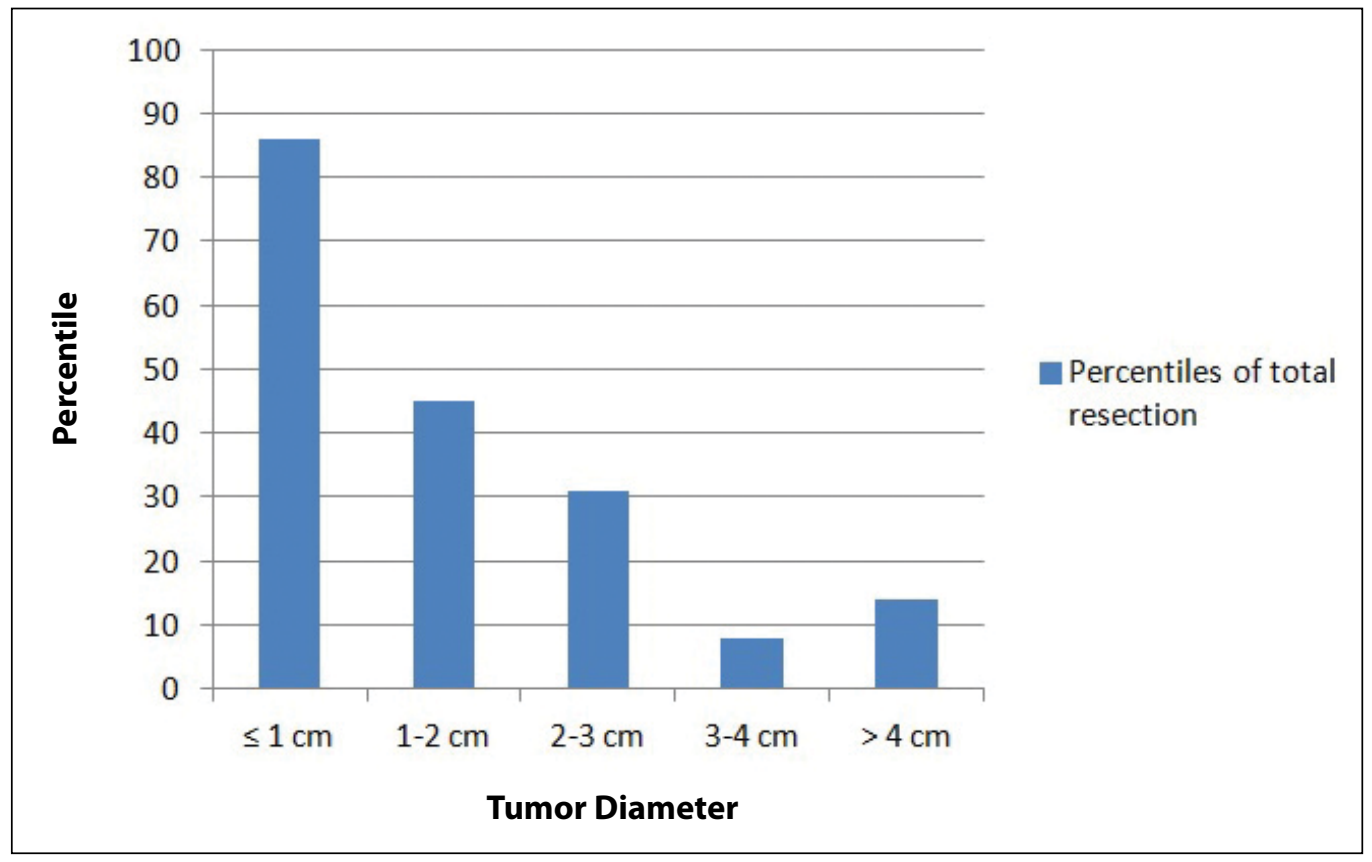

Figure 1: Percentiles of total resection in sellar tumors. Rates of total resection are significantly higher in tumors with smaller diameters. 
(Figure 2). Pre-operative optic chiasm compression was the most predominant in non-secretory sellar tumors among all sellar tumors. The phenomenon was determined in $89 \%$ of nonfunctioning pituitary adenomas, $91 \%$ of meningiomas, and $60 \%$ of craniopharyngiomas. Among all secretory pituitary tumors, patients with prolactinoma presented with the highest rates of optic chiasm compression (65\%). Surgical success in removing optic chiasm compression was statistically higher than the surgical success in removing cavernous sinus invasion in all sellar tumors (Table IV).

Post-operative hormonal remission rates were $62 \%$ in patients with acromegaly and $71.4 \%$ in patients with Cushing's disease. However, post-operative hormonal remission could be attained in only $40.4 \%$ of patients with prolactinoma.
Hormonal remission could be attained despite post-operative residual tissue in 9 acromegaly cases, and one of each of prolactinoma, Cushing's disease, and TSHoma cases.

In the evaluation of rates of post-remission recurrence, the recurrence rates were $41.1 \%$ in prolactinoma cases with a mean follow-up of 36.5 months (3-138 months), and $11.4 \%$ in acromegaly cases with a mean follow-up of 48 months (1-138 months). Additionally, enhancement in tumor size or novel adenoma formation in residual tumor was observed in $18.6 \%$ of nonfunctioning pituitary adenoma cases with a mean follow-up of 30 months (3-115 months). Recurrence was statistically significantly most common in prolactinomas among all pituitary adenomas.

Table IV: Rates of Surgical Success in Removing Cavernous Sinus Invasion and Compression of Optic Chiasm

\begin{tabular}{|c|c|c|c|c|c|c|}
\hline & $\begin{array}{c}\text { Preop. } \\
\text { cavernous } \\
\text { sinus } \\
\text { invasion }\end{array}$ & $\begin{array}{l}\text { Postop. } \\
\text { cavernous } \\
\text { sinus } \\
\text { invasion }\end{array}$ & $\begin{array}{l}\text { Rates of } \\
\text { surgical } \\
\text { success }\end{array}$ & $\begin{array}{l}\text { Preop. } \\
\text { comp. } \\
\text { of optic } \\
\text { chiasm }\end{array}$ & $\begin{array}{l}\text { Postop. } \\
\text { comp. } \\
\text { of optic } \\
\text { chiasm }\end{array}$ & $\begin{array}{l}\text { Rates of } \\
\text { surgical } \\
\text { success }\end{array}$ \\
\hline Acromegaly & 29 & 12 & $\% 59$ & 23 & 3 & $\% 87$ \\
\hline Nonfunctioning adenoma & 57 & 33 & $\% 42$ & 67 & 12 & $\% 82$ \\
\hline Prolactinoma & 34 & 21 & $\% 38$ & 27 & 4 & $\% 85$ \\
\hline Cushing's disease & - & - & - & - & - & - \\
\hline TSHoma & 2 & 1 & $\% 50$ & - & - & - \\
\hline Craniopharyngioma & 10 & 3 & $\% 70$ & 9 & 2 & $\% 78$ \\
\hline Meningioma & 9 & 4 & $\% 55$ & 11 & 3 & $\% 73$ \\
\hline Other sellar tumors & 9 & 6 & $\% 33$ & 9 & 1 & $\% 88$ \\
\hline
\end{tabular}

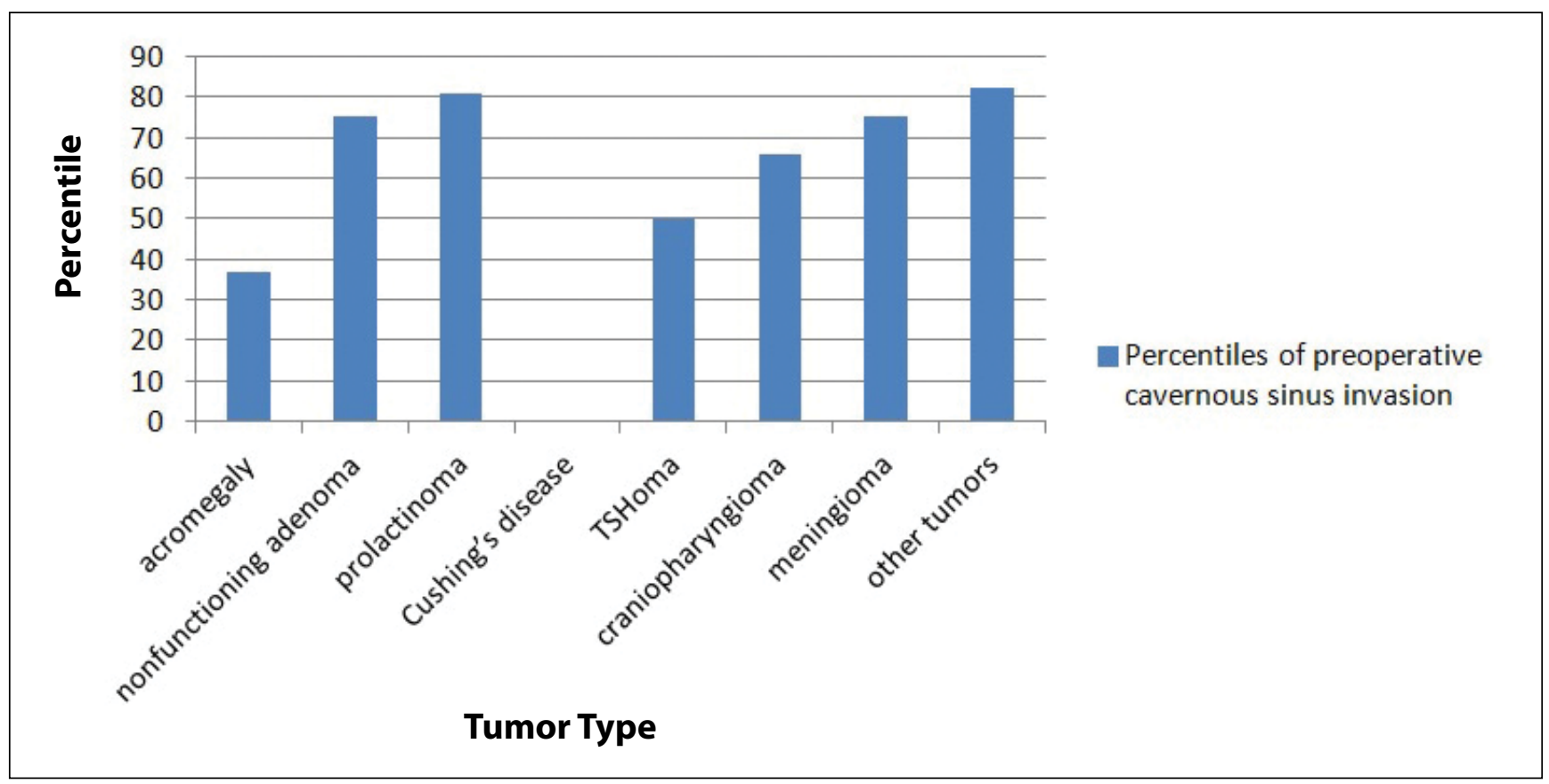

Figure 2: Percentiles of preoperative cavernous sinus invasion in sellar tumors. Acromegaly: 37\%, nonfunctioning pituitary adenoma $75 \%$, prolactinoma $81 \%$, Cushing's disease $0 \%$, TSHoma 50\%, craniopharyngioma $66 \%$, meningioma $75 \%$, and other tumors: $82 \%$. 
The most commonly deficient hormones were gonadotropins (36\%) and TSH (33\%) when all sellar tumors were evaluated together. Individual assessment of each disorder demonstrated that TSH deficiency was more common in acromegaly and meningioma, and FSH-LH deficiencies were more common in the remaining tumors (Table V). Post-operative hormonal deficiency was statistically significantly more common in nonsecretory sellar tumors compared to secretory adenomas ( $p=$ 0.001 ). Post-operative pituitary deficiency was most common in nonfunctioning pituitary adenomas (71\%), followed by craniopharyngiomas (67\%) and finally prolactinomas (60\%).

When the acromegaly group was evaluated and the age at diagnosis and prognosis compared, the hormonal remission rate was lower in the $30-50$ years age group, which was the most common age stratum $(p=0.06)$. Rates of post-operative residual tissue, recurrence, and re-operation were similarly higher in this age group in acromegaly cases, but not to a statistically significant degree. Recurrence rates were higher in females compared to males in the comparison of gender and hormonal remission with recurrence rates in acromegaly $(p=0.007)$. However, no correlation was determined between hormonal remission and gender $(p=0.40)$. In the evaluation of the relationship between tumor size and prognosis, the amount of residual tissue was greater in macroadenomas compared to microadenomas $(p=0.002)$. However, no significant relationship was determined between tumor size and recurrence as well as re-operation rates in the acromegaly group. Hormonal remission was less common in giant adenomas compared to other adenomas $(p=0.004)$. In the assessment of the prognostic importance of cavernous sinus invasion, no significant relationship was determined between cavernous sinus invasion and hormonal remission and recurrence. However, rates of residual tissue and reoperation were higher in acromegaly cases with cavernous sinus invasion compared to those without invasion $(p=0.01)$.

The prognostic importance of the IGF-1 level was also examined and hormonal remission was observed in 15 of 35 acromegaly cases (42.9\%) with IGF-1 levels $>850 \mathrm{ng} / \mathrm{mL}$, and 34 of 44 acromegaly cases (77.3\%) with IGF-1 levels $\leq$
$850 \mathrm{ng} / \mathrm{mL}$. Hormonal remission was compared in these two subgroups of acromegaly cases and the results were statistically significant $(p=0.002)$. Additionally, recurrence rates were higher in patients with an IGF-1 level $>850 \mathrm{ng} / \mathrm{ml}$, although not to a statistically significant degree $(p=0.151)$. However, cavernous sinus invasion, residual tissue and reoperation rates were significantly higher in patients with IGF1 levels $>850 \mathrm{ng} / \mathrm{mL}$.

Age and prognosis were not significantly associated in the prolactinoma cases. However, in the assessment of prognostic importance of gender, hormonal remission was more common in the female prolactinoma patients $(p=$ 0.048). In terms of tumor size, hormonal remission was more common in cases with microadenomas compared to those with macroadenomas $(p=0.029)$. Additionally, the amount of residual tissue was greater in macroadenomas $(p=0.03)$. In the evaluation of the relationship between cavernous sinus invasion and prognosis, hormonal remission was less common in prolactinoma cases with compared to those without cavernous sinus invasion $(p=0.003)$. The rate of residual tissue was also higher in prolactinoma cases with cavernous sinus invasion $(p=0.009)$.

The relationship between prognosis and tumor size was investigated in nonfunctioning pituitary adenoma cases and it was noted that rates of post-operative residual tissue and re-operation were higher in cases with giant nonfunctioning adenomas $(p=0.009)$. However, no significant increase of recurrence was determined in patients with giant nonfunctioning adenomas. Relatedly, when all patients with nonfunctioning pituitary adenoma were considered together, no relationship was found between tumor size and recurrence rates. Residual tissue and re-operation rates were higher in cases with cavernous sinus invasion in nonfunctioning adenomas. Recurrence rates were also higher in nonfunctioning adenomas with post-operative residual tissue in our study $(p=0.038)$. Cavernous sinus invasion was determined in $76 \%$ of nonfunctioning adenomas and recurrence was observed in $21 \%$ of those with cavernous sinus invasion and $11 \%$ of those without ( $p=0.345$, not significant).

Table V: Postoperative Hormone Deficiencies in Pituitary Adenomas and other Seller Tumors

\begin{tabular}{|c|c|c|c|c|c|c|}
\hline & $\begin{array}{l}\text { Number of } \\
\text { patients }\end{array}$ & $\begin{array}{l}\text { Postop. } \\
\text { FSH-LH deficiency }\end{array}$ & $\begin{array}{l}\text { Postop. TSH } \\
\text { deficiency }\end{array}$ & $\begin{array}{l}\text { Postop. ACTH } \\
\text { deficiency }\end{array}$ & $\begin{array}{l}\text { Postop. GH } \\
\text { deficiency }\end{array}$ & $\begin{array}{l}\text { Postop. ADH } \\
\text { deficiency }\end{array}$ \\
\hline Acromegaly & 79 & 10 & 15 & 8 & 1 & 2 \\
\hline Nonfunctioning adenoma & 75 & 40 & 34 & 24 & 14 & 4 \\
\hline Prolactinoma & 42 & 22 & 15 & 5 & 5 & 4 \\
\hline Cushing's disease & 7 & - & 1 & - & - & 1 \\
\hline TSHoma & 2 & - & - & - & - & - \\
\hline Craniopharyngioma & 15 & 9 & 7 & 6 & 3 & 3 \\
\hline Meningioma & 12 & 2 & 5 & 2 & 1 & - \\
\hline Other sellar tumors & 11 & 4 & 3 & 3 & 3 & - \\
\hline TOTAL & 243 & 87 & 79 & 49 & 26 & 14 \\
\hline
\end{tabular}




\section{DISCUSSION}

Pituitary adenomas are distinguished from other intracranial tumors by clinical, pathological, and biological features. Most of these features are related to their ability to synthesize and secrete hormones. These tumors therefore result in certain endocrinological disorders. About $70 \%$ of pituitary tumors are hormonally active. Pituitary adenomas have differing enlargement, secretory, and invasion properties that cannot be pre-determined. Certain tumors remain as microadenomas with little enhancement over time, whereas others may be rapidly progressive with invasion of neighboring bony, vascular and neural structures.

Several parameters have been reported in the literature to aid in determining the prognosis in pituitary adenomas. Hormonal remission and recurrence following pituitary adenoma surgery has been demonstrated to be specified by age, gender, tumor size, cavernous sinus invasion, basal hormone level and immunohistochemical staining features in functional adenomas in a metaanalysis of 143 studies performed in 2012 (17).

Ten-year follow-up results of the German Pituitary Tumor Registry Center included pituitary adenomas in $84.6 \%$ of 4122 operated sellar tumors followed in frequency by craniopharyngioma, meningioma, Rathke cleft cyst and other sellar tumors (18). In our study, there were 205 (84.4\%) pituitary adenomas and 38 (15.6\%) other sellar tumors for a total of 243 cases.

Raverot et al. have reported rates of hormonal remission as $82 \%$ in females and $28 \%$ in males in patients with prolactinoma (16). Only a few studies were found in the metaanalysis of Roelfsema et al. on the effect of age at diagnosis and gender on prognosis in pituitary adenomas (17). Similarly, no significant relationship was determined between age at diagnosis and prognosis of sellar tumors in our study. However, a substantive relationship was determined between gender and prognosis in cases of acromegaly and prolactinoma. Recurrence rates were higher in female cases of acromegaly, whereas postoperative hormonal remission was more common in female prolactinoma cases. The higher rates of remission in female patients with prolactinoma might be associated with smaller mean tumor sizes in females compared to males, and less surrounding tissue invasion, resulting in greater chances of curative surgery.

Nomikos et al. have examined 668 cases of acromegaly and determined post-operative hormonal remission in $75 \%$ of 142 patients with microadenomas, $48 \%$ of 390 patients with macroadenomas, and $8 \%$ of giant adenomas (15). Beauregard et al. have reported remission rates as $82 \%$ in microadenomas, and $60 \%$ in macroadenomas in their study of 103 acromegaly cases (4). Fifteen literature series on acromegaly have demonstrated that remission rates were $61-91 \%$ in microadenomas and $23-71 \%$ in macroadenomas (15). Raverot et al. have examined 94 cases with prolactinoma and reported post-operative remission in
40 of 43 patients with microadenoma (92\%), 19 of 41 patients with macroadenoma (47\%), and 1 of 10 patients with giant adenoma (10\%) (16). Rates of remission have been reported to be higher in microprolactinoma and female prolactinoma cases in the study of Arasho et al. (2). In our study, postoperative hormonal remission was more common in microprolactinoma cases. Similarly, post-operative hormonal remission was less common in cases with giant adenomas of acromegaly patients. However, no significant relationship was determined between tumor size and recurrence rates in cases with acromegaly and prolactinoma. The higher rates of postoperative hormonal remission in pituitary tumor cases with microadenoma compared to macroadenoma was explained with greater total resection rates in microadenomas.

Ferreira et al. have examined 117 non-functioning pituitary adenomas and determined a relationship between tumor size and recurrence, re-operation and hormonal deficiency (7). A metaanalysis has reported no association between tumor size and recurrence in nonfunctioning adenomas (17). Additionally, Brochier et al. have reported an association between post-operative residual tissue and recurrence (5). Recurrence rates were higher in nonfunctioning adenomas with post-operative residual tissue in our study too.

In the study by Raverot et al. on 94 prolactinoma cases aimed at demonstrating the relationship between tumor invasion and remission, post-operative remission was determined in only 2 out of 33 cases (6\%) with cavernous sinus invasion. Post-operative remission was observed in 58 of 61 (95\%) patients without cavernous sinus invasion (16). Yet another study demonstrated remission in $21.6 \%$ and $72.2 \%$ of patients with and without cavernous sinus invasion, respectively (15). In our study, hormonal remission was higher in prolactinomas and acromegaly cases without cavernous sinus invasion, but this was not significant in the acromegaly group.

Brochier et al. have examined nonfunctioning pituitary adenomas in 142 patients and found cavernous sinus invasion in $54 \%$. They determined recurrence in $51 \%$ and $27 \%$ of those with and without cavernous sinus invasion, respectively (5). A strong correlation has been determined between cavernous sinus invasion and recurrence in nonfunctioning pituitary adenomas in other studies and our study $(1,6,8-10,12-14)$.

Currently, total surgical resection is known to be very difficult in cases with cavernous sinus invasion. In cases of hormonally active pituitary adenomas, residual tumor tissue from subtotal resection will continue to secrete hormones. Such tumors might exhibit aggressive behavior, recur, enlarge and even require repetitive operations despite surgical treatment. Cavernous sinus invasion should be therefore determined and classification should be performed pre-operatively in pituitary adenomas to aid substantially in planning the surgery and post-surgical treatment approaches.

Basal hormone levels might yield important information regarding the prognosis in acromegaly. Jane et al. have examined 60 acromegaly cases and determined remission 
rates as $100 \%$ in 21 patients with pre-operative IGF-1 levels $<625 \mathrm{ng} / \mathrm{mL}, 76.5 \%$ in 17 patients with IGF-1 levels of 625 $825 \mathrm{ng} / \mathrm{mL}$, and $31.6 \%$ in 19 patients with IGF-1 levels $>825$ $\mathrm{ng} / \mathrm{mL}$ (11). The mean IGF-1 level was $631 \mathrm{ng} / \mathrm{mL}$ in remitting patients and $952.6 \mathrm{ng} / \mathrm{mL}$ in non-remitting patients in the same study. In our study, the mean IGF-1 level was $808 \pm 42$ $\mathrm{ng} / \mathrm{mL}$ in remitting acromegaly cases but $928 \pm 48 \mathrm{ng} / \mathrm{mL}$ in non-remitting cases. Additionally, post-operative hormonal remission was observed in $77.3 \%$ of 44 acromegaly patients with a pre-operative IGF-1 level $\leq 850 \mathrm{ng} / \mathrm{mL}$ and $42.9 \%$ of 35 acromegaly patients with an IGF-1 level $>850 \mathrm{ng} / \mathrm{mL}$, and this difference was statistically significant. Accordingly, the cut-off IGF-1 value might be set as $850 \mathrm{ng} / \mathrm{mL}$ rather than 825 $\mathrm{ng} / \mathrm{mL}$ to pre-determine post-operative hormonal remission in patients diagnosed with acromegaly. Post-operative recurrence should be watched more closely in patients with acromegaly and an IGF-1 level above $850 \mathrm{ng} / \mathrm{mL}$. Our results have increased the basal cut-off value of IGF-1, which has important prognostic value in acromegaly. However, there seems to be no substantial difference between the two recommended cut-off values, i.e. $825 \mathrm{ng} / \mathrm{mL}$ and $850 \mathrm{ng} /$ $\mathrm{mL}$, because of the low number of our patients ( 6 patients) with an IGF-1 value between 800 and $851 \mathrm{ng} / \mathrm{mL}$. Therefore, further studies should be performed on this issue.

\section{CONCLUSIONS}

The total resection rate of pituitary adenoma and other sellar tumors was less than $50 \%$ in our study. Higher total resection rates ensure a better prognosis in pituitary adenomas. Therefore, surgical success increases and the complication plus re-operation rates decrease in the presence of an experienced surgeon and surgical team. Chances of curative surgery and hence hormonal remission were low in adenomas with optic chiasm compression and cavernous sinus invasion. Cavernous sinus invasion complicates and even precludes chances of total resection. Therefore, cavernous sinus invasion might be accepted as the main prognostic factor in pituitary adenomas. Cavernous sinus invasion should be determined and classification should be performed preoperatively in pituitary adenomas in order to determine the surgical procedure and post-surgical therapies. In addition, post-operative hormonal remission might be pre-determined from basal hormone levels in acromegaly. We suggest an IGF1 value of $850 \mathrm{ng} / \mathrm{ml}$ as a cut-off value determining hormonal remission in acromegaly.

In short, there is no single prognostic factor in sellar region tumors. The effect of the surgeon's experience on treatment is certainly undisputed. However, the long-term follow-up results of our study demonstrated that factors common to all sellar region tumors including tumor type, tumor size, total resection, and cavernous sinus invasion in addition to tumor type-specific factors including gender and hormone levels play important roles in the prognosis.

\section{REFERENCES}

1. Alahmadi H, Dehdashti AR, Gentili F: Endoscopic endonasal surgery in recurrent and residual pituitary adenomas after microscopic resection. World Neurosurg 77(3-4):540-547, 2012

2. Arasho BD, Schaller B, Sandu N, Zenebe G: Gender-related differences in pituitary adenomas. Exp Clin Endocrinol Diabetes 117(10):567-572, 2009

3. Asa SL: Practical pituitary pathology: What does the pathologist need to know? Arch Pathol Lab Med 132:1231-1240, 2008

4. Beauregard C, Truong U, Hardy J, Serri O: Long-term outcome and mortality after transsphenoidal adenomectomy for acromegaly. Clin Endocrinol (Oxf) 58(1):86-91, 2003

5. Brochier S, Galland F, Kujas M Parker F, Gaillard S, Raftopoulos C, Young J, Alexopoulou O, Maiter D, Chanson P: Factors predicting relapse of nonfunctioning pituitary macroadenomas after neurosurgery: A study of 142 patients. European Journal of Endocrinology 163:193-200, 2010

6. Chang EF, Zada G, Sughrue ME, Wilson CB, Blevins LS, Kunwar S: Long term outcome following repeat transsphenoidal surgery for recurrent endocrine-inactive pituitary adenomas. Pituitary 13(3):223-229, 2010

7. Ferreira JE, de Mello PA, de Magalhães AV: Non-functioning pituitary adenomas: Clinical features and immunohistochemistry. Arq Neuropsiquiatr 63(4):1070-1078, 2005

8. Greenman Y, Ouaknine G, Veshchev I, Reider-Groswasser II, Segev Y, Stern N: Postoperative surveillance of clinically nonfunctioning pituitary macroadenomas: Markers of tumour quiescence and regrowth. Clin Endocrinol (Oxf) 58(6):763769, 2003

9. Greenman $Y$, Stern N: Non-functioning pituitary adenomas. Best Pract Res Clin Endocrinol Metab 23(5):625-638, 2009

10. Honegger J, Ernemann U, Psaras T, Will B: Objective criteria for successful transsphenoidal removal of suprasellar nonfunctioning pituitary adenomas. A prospective study. Acta Neurochir (Wien) 149(1):21-29, 2007

11. Jane JA Jr, Starke RM, Elzoghby MA, Reames DL, Payne SC, Thorner MO, Marshall JC, Laws ER Jr, Vance ML: Endoscopic transsphenoidal surgery for acromegaly: Remission using modern criteria, complications, and predictors of outcome. J Clin Endocrinol Metab 96(9):2732-2740, 2011

12. Losa M, Mortini P, Barzaghi R, Ribotto P, Terreni MR, Marzoli SB, Pieralli S, Giovanelli M: Early results of surgery in patients with nonfunctioning pituitary adenoma and analysis of the risk of tumor recurrence. J Neurosurg 108(3):525-532, 2008

13. Messerer M, De Battista JC, Raverot G, Kassis S, Dubourg J, Lapras V, Trouillas J, Perrin G, Jouanneau E: Evidence of improved surgical outcome following endoscopy for nonfunctioning pituitary adenoma removal. Neurosurg Focus 30(4):E11, 2011

14. Nishioka H, Inoshita N, Sano T, Fukuhara N, Yamada S: Correlation between histological subtypes and MRI findings in clinically nonfunctioning pituitary adenomas. Endocr Pathol 23(3):151-156, 2012 
15. Nomikos P, Buchfelder M, Fahlbusch R: The outcome of surgery in 668 patients with acromegaly using current criteria of biochemical 'cure'. Eur J Endocrinol 152(3):379-387, 2005

16. Raverot G, Wierinckx A, Dantony E, Auger C, Chapas G, Villeneuve $L$, Brue T, Figarella-Branger D, Roy $P$, Jouanneau $E$, Jan M, Lachuer J, Trouillas J; HYPOPRONOS: Prognostic factors in prolactin pituitary tumors: clinical, histological, and molecular data from a series of 94 patients with a long postoperative follow-up. J Clin Endocrinol Metab 95(4):1708-1716, 2010

17. Roelfsema F, Biermasz NR, Pereira AM: Clinical factors involved in the recurrence of pituitary adenomas after surgical remission: A structured review and meta-analysis. Pituitary 15(1):71-83, 2012
18. Saeger W, Lüdecke DK, Buchfelder M, Fahlbusch R, Quabbe $\mathrm{HJ}$, Petersenn S: Pathohistological classification of pituitary tumors: 10 years of experience with the German Pituitary Tumor Registry. Eur J Endocrinol 156(2):203-216, 2007

19. Thapar K, Kovacs K, Scheithauer BW, Muller PJ: Classification and pathology of sellar and parasellar tumors. In: Tindall GT, Cooper PR, Barrow BL (ed), The Practice of Neurosurgery. Lippincott Williams \& Wilkins, 1995: 1021-1065 